Supporting information

\title{
Development of reactive oxygen species-triggered degradable nanoparticles using oligoproline-containing peptides
}

\author{
Riku Kawasaki, ${ }^{\dagger}$ Kousuke Tsuchiya, ${ }^{*}, \dagger, \S$ Yutaka Kodama,${ }^{\ddagger}$ and Keiji Numata ${ }^{*}, \dagger$, \\ † Biomacromolecules Research Team, RIKEN Center for Sustainable Resource Science, 2-1 Hirosawa, Wako, \\ Saitama 351-0198, Japan. \\ ¥ Utsunomiya University, 350 Minemachi, Utsunomiya, Tochigi 321-8505, Japan. \\ $\S$ Kyoto University, Katsura, Nishikyoku, Kyoto, 615-8510, Japan.
}

S3 Supplemental Table

S4-S16 Supplemental Figure 

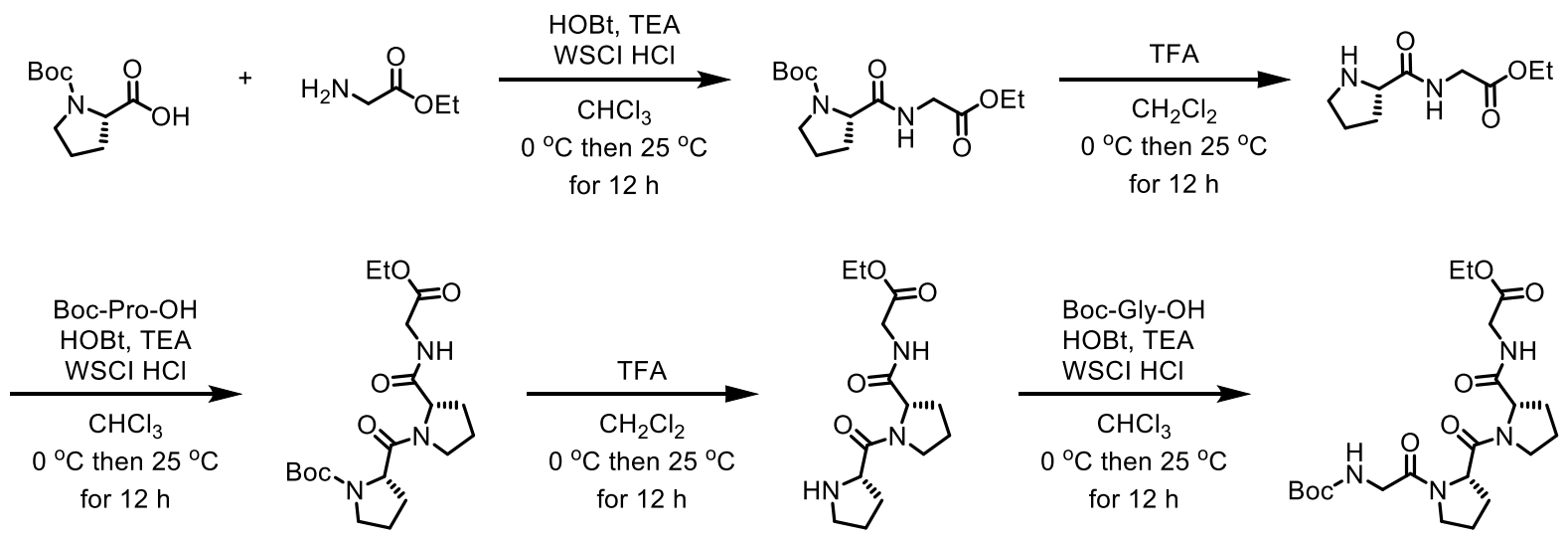

Scheme S1. Synthesis of GPPG peptide via liquid phase synthesis.

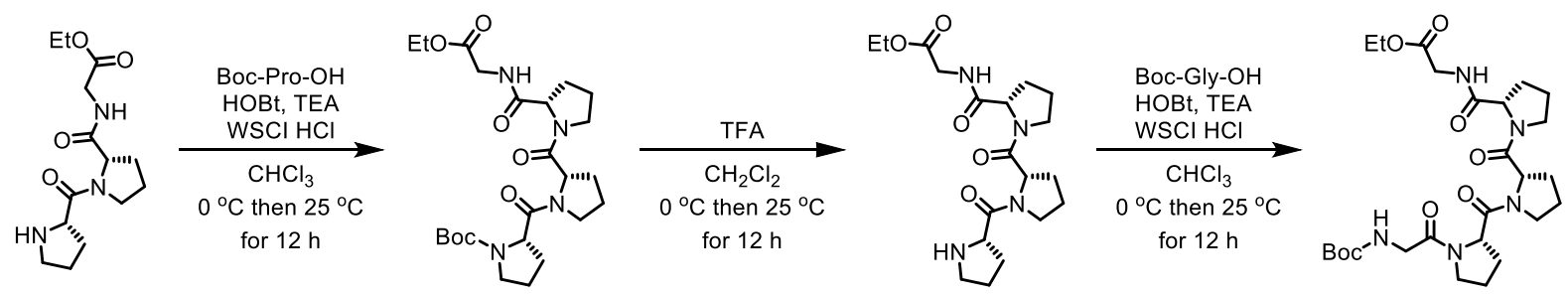

Scheme S2. Synthesis of GPPPG peptide via liquid phase synthesis. 
Table S1. Solution properties of oligoproline-containing peptide-based nanoparticles.

\begin{tabular}{lccll}
\hline Peptide & $R_{\mathrm{H}} / \mathrm{nm}^{[\mathrm{a}]}$ & $\mathrm{PDI}^{[\mathrm{b}]}$ & $\zeta / \mathrm{mV}^{[\mathrm{c}]}$ & $\begin{array}{l}\mathrm{CMC} \\
/ \mathrm{mg} \mathrm{mL}^{-1[\mathrm{~d}]}\end{array}$ \\
\hline GPPG & $135 \pm 5$ & 0.28 & $-2.63 \pm 0.6$ & 0.008 \\
GPPPG & $79 \pm 1$ & 0.26 & $-2.70 \pm 0.6$ & 0.0001 \\
\hline
\end{tabular}

${ }^{[a]}$ Hydrodynamic radius. ${ }^{[b]}$ PDI value calculated by cumulant method. ${ }^{[c]}$ Zeta potential. ${ }^{[d]}$ $\mathrm{CMC}$ value determined by fluorescent probe method using pyrene.

Table S2. Complexation of peptide nanoparticles with rhodamine B. ${ }^{[a]}$

\begin{tabular}{lllll}
\hline Peptide & $R_{\mathrm{H}} / \mathrm{nm}^{[\mathrm{b}]}$ & $\mathrm{PDI}^{[\mathrm{c}]}$ & $\begin{array}{l}\text { Amount } \\
\text { rhodamine B } \\
/ \mathrm{mg} \mathrm{mL}^{-1[\mathrm{~d}]}\end{array}$ & of $\begin{array}{l}\text { Efficiency } \\
/ \% \%^{[\mathrm{d}]}\end{array}$ \\
\hline GPPG & $130 \pm 4$ & 0.21 & $0.043 \pm 0.08$ & $11 \pm 3$ \\
GPPPG & $85 \pm 2$ & 0.18 & $0.046 \pm 0.05$ & $12 \pm 2$ \\
\hline
\end{tabular}

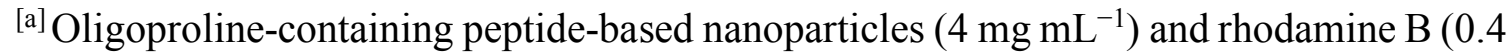
mg mL ${ }^{-1}$ ) were co-incubated for $12 \mathrm{~h} .{ }^{[b]}$ Hydrodynamic radius. ${ }^{[c]}$ PDI value calculated by cumulant method. [d] The complexed amount and of rhodamine and complexation efficiency were determined by measuring absorbance at $550 \mathrm{~nm}$ using UV-Vis spectrometer. 


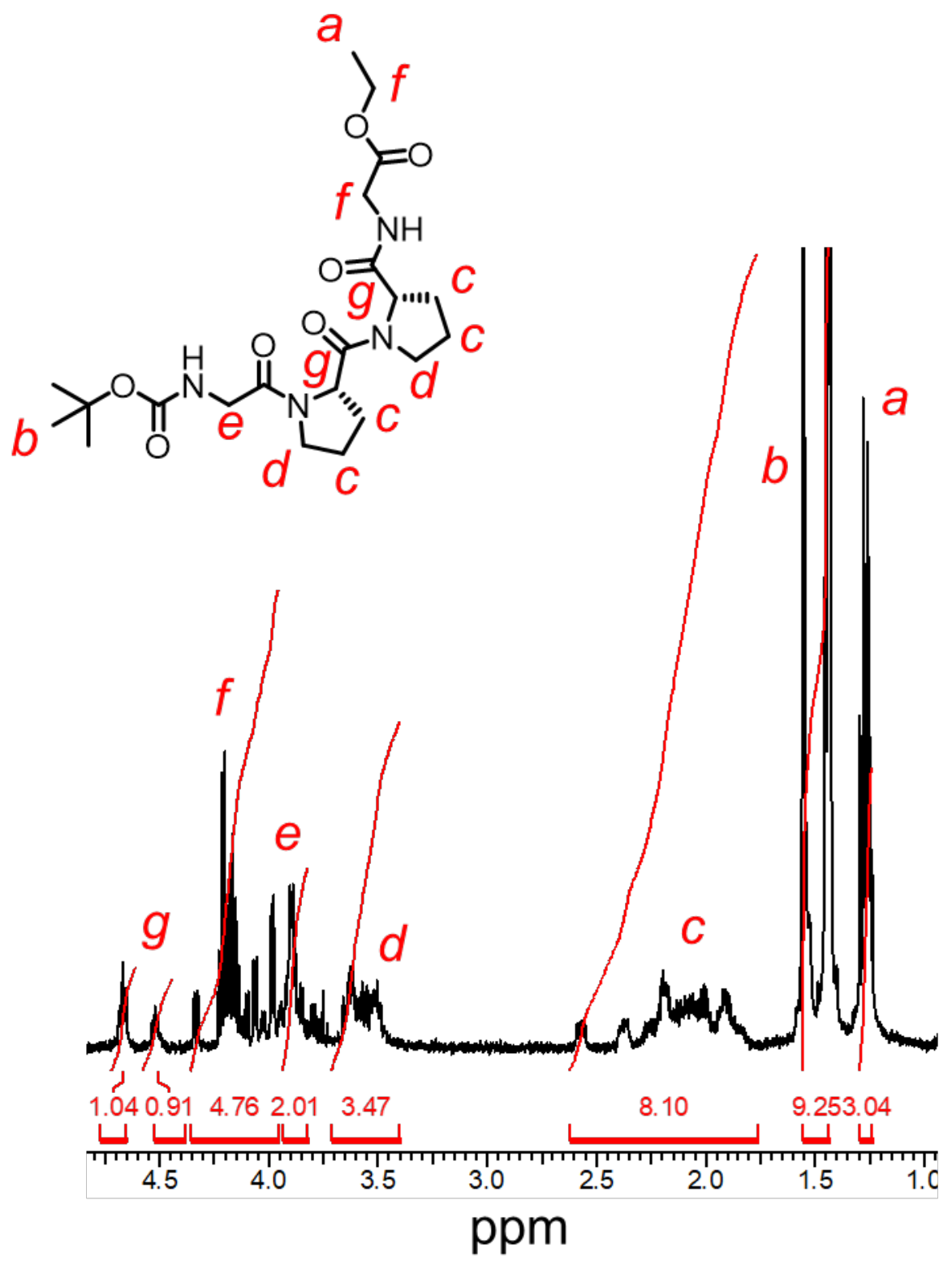

Figure S1. ${ }^{1} \mathrm{H}$ NMR spectrum of GPPG peptide in $\mathrm{CDCl}_{3}$. 


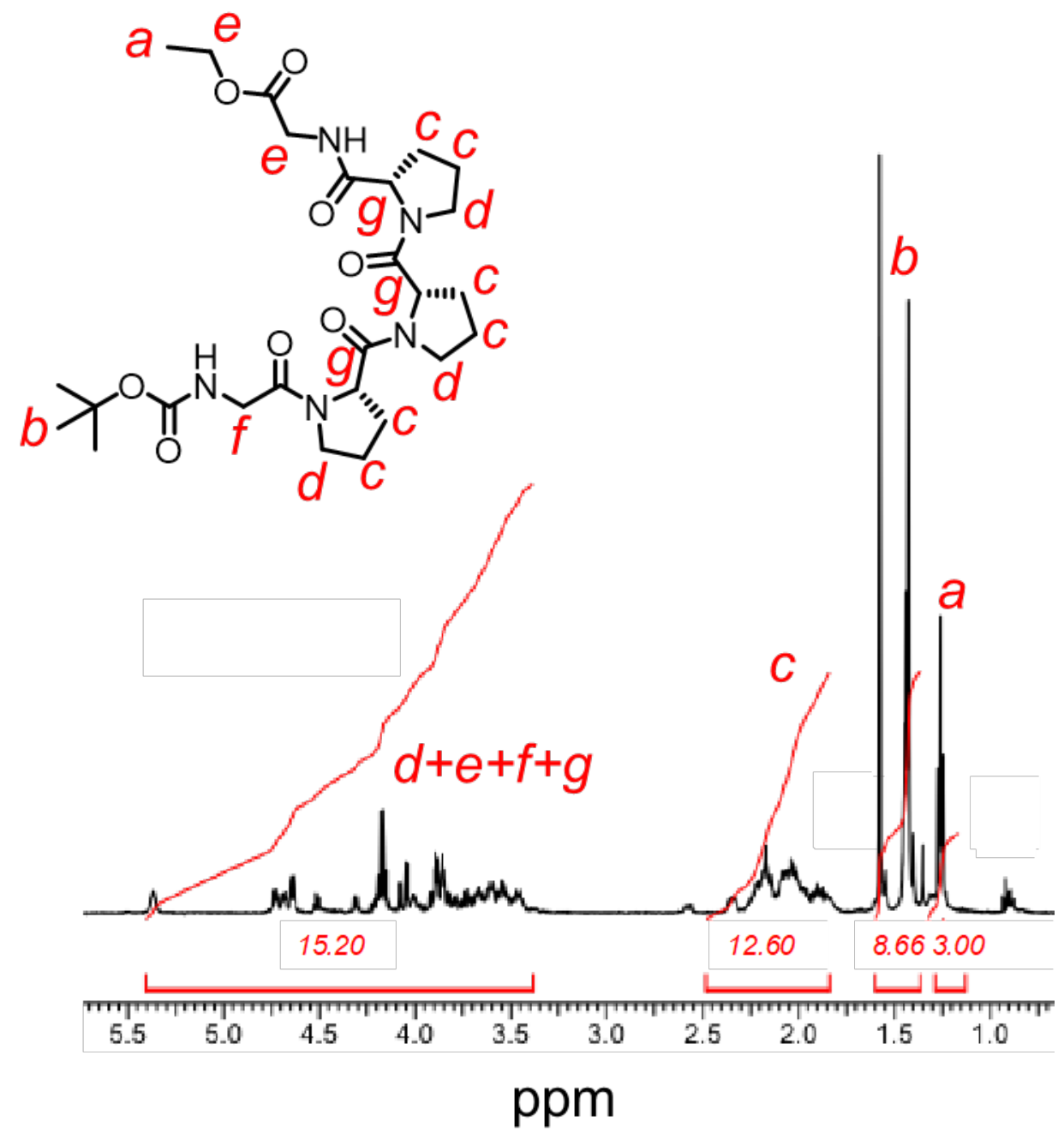

Figure S2. ${ }^{1} \mathrm{H}$ NMR spectrum of GPPPG peptide in $\mathrm{CDCl}_{3}$. 


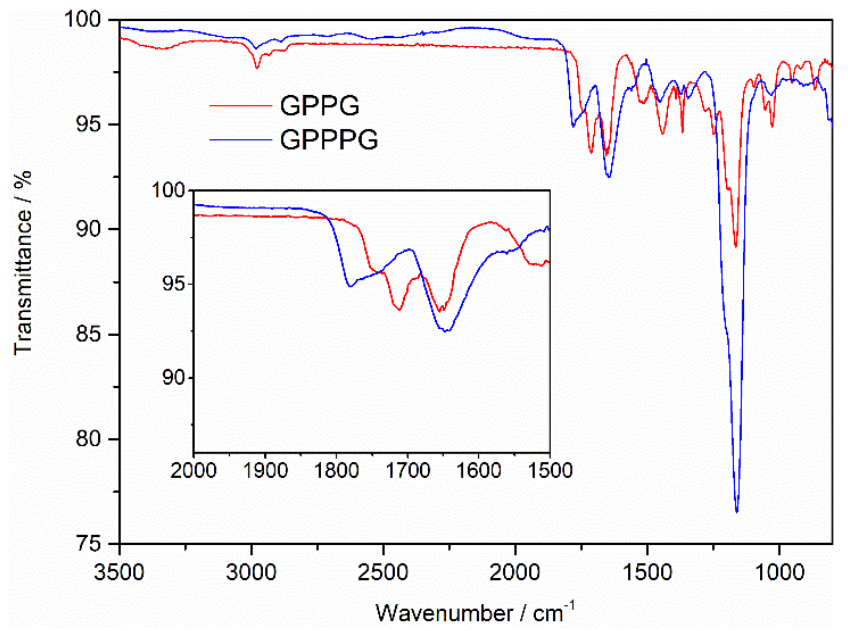

Figure S3. IR spectra of oligoproline-containing peptides (red: GPPG, blue: GPPPG). Inset is the expanded spectra in the region showing amide peaks. 
(a)
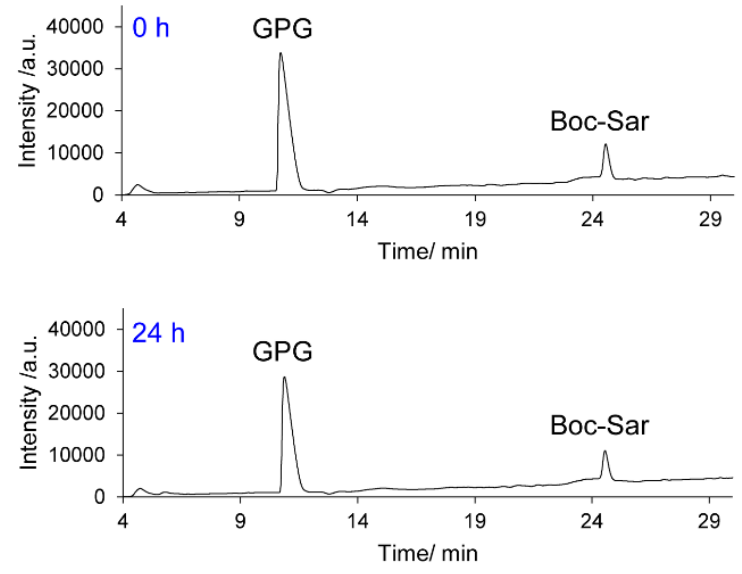

(b)
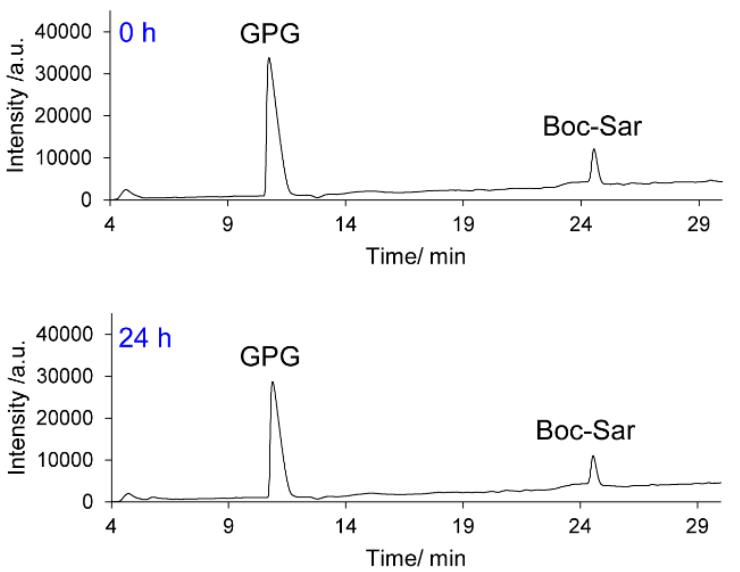

Figure S4. HPLC profiles of GPG peptide treated with (a) $\mathrm{CuSO}_{4}(50 \mu \mathrm{M})$ and (b) $\mathrm{H}_{2} \mathrm{O}_{2}(1000$ $\mu \mathrm{M})$ and $\mathrm{CuSO}_{4}(50 \mu \mathrm{M})$ for 0 and $24 \mathrm{~h}$. Boc-Sar was used as an internal standard. 
(a)
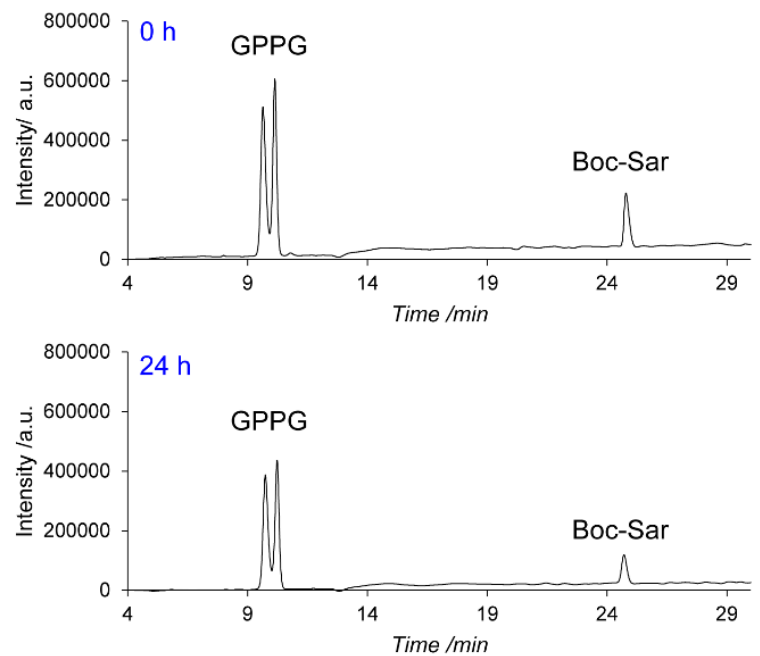

(b)
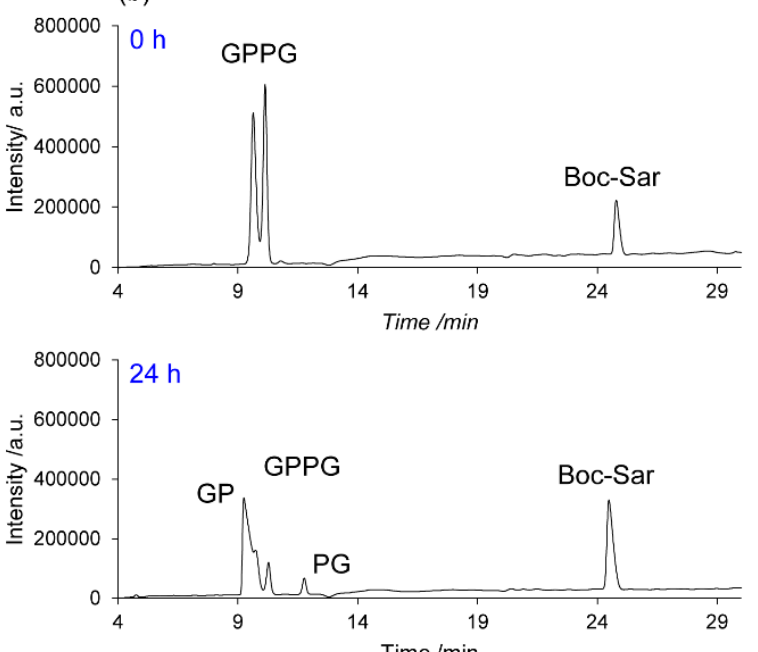

Figure S5. HPLC profiles of GPPG peptide treated with (a) $\mathrm{CuSO}_{4}(50 \mu \mathrm{M})$ and (b) $\mathrm{H}_{2} \mathrm{O}_{2}$ $(1000 \mu \mathrm{M})$ and $\mathrm{CuSO}_{4}(50 \mu \mathrm{M})$ for 0 and $24 \mathrm{~h}$. Boc-Sar was used as an internal standard. 
(a)
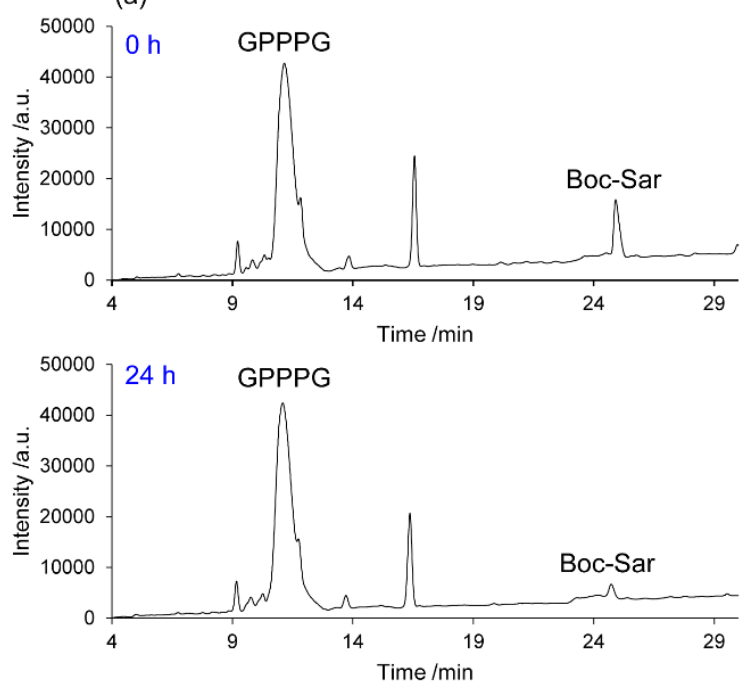

(b)
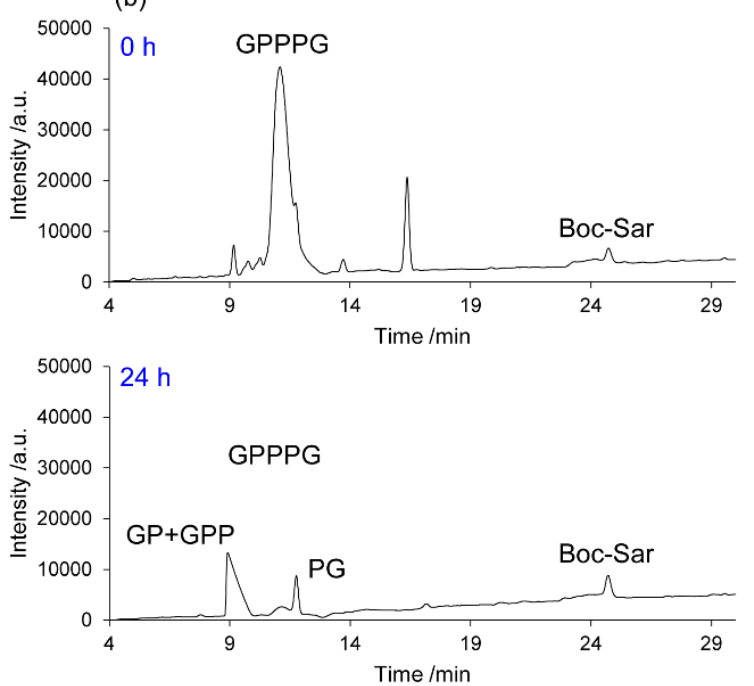

Figure S6. HPLC profiles of GPPPG peptide treated with (a) $\mathrm{CuSO}_{4}(50 \mu \mathrm{M})$ and (b) $\mathrm{H}_{2} \mathrm{O}_{2}$ $(1000 \mu \mathrm{M})$ and $\mathrm{CuSO}_{4}(50 \mu \mathrm{M})$ for 0 and $24 \mathrm{~h}$. Boc-Sar was used as an internal standard. 


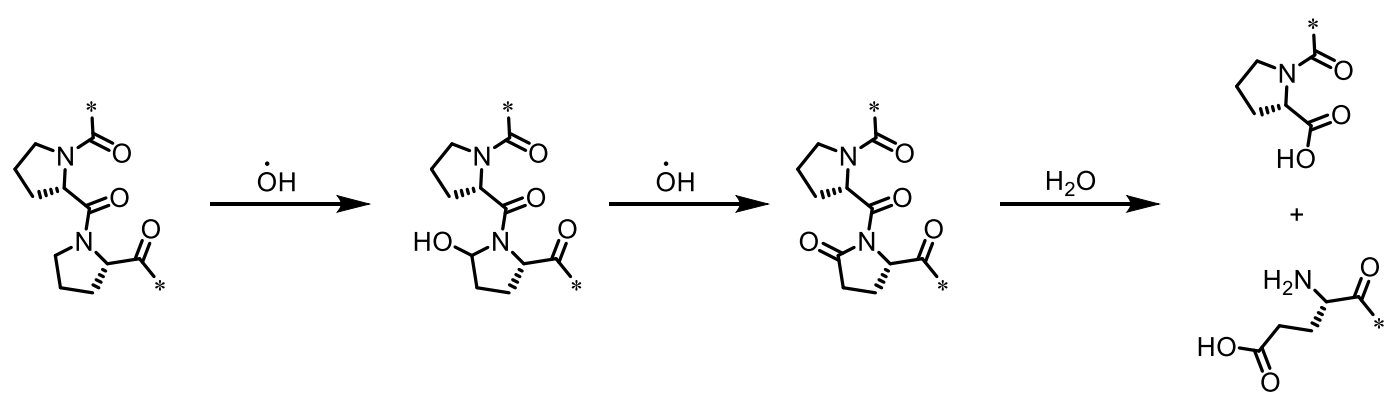

Figure S7. Plausible scheme for the degradation of ProPro-containing peptides mediated by hydroxyl radicals. 


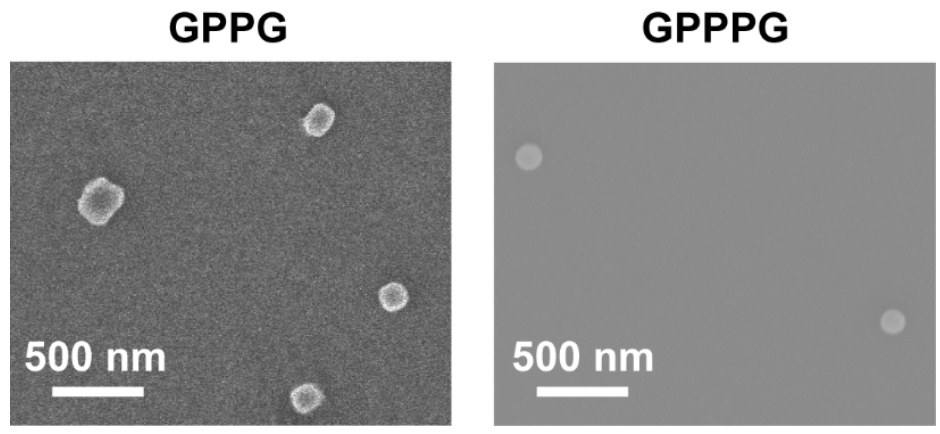

Figure S8. FE-SEM images of the peptide nanoparticles obtained from GPPG and GPPPG peptides. 

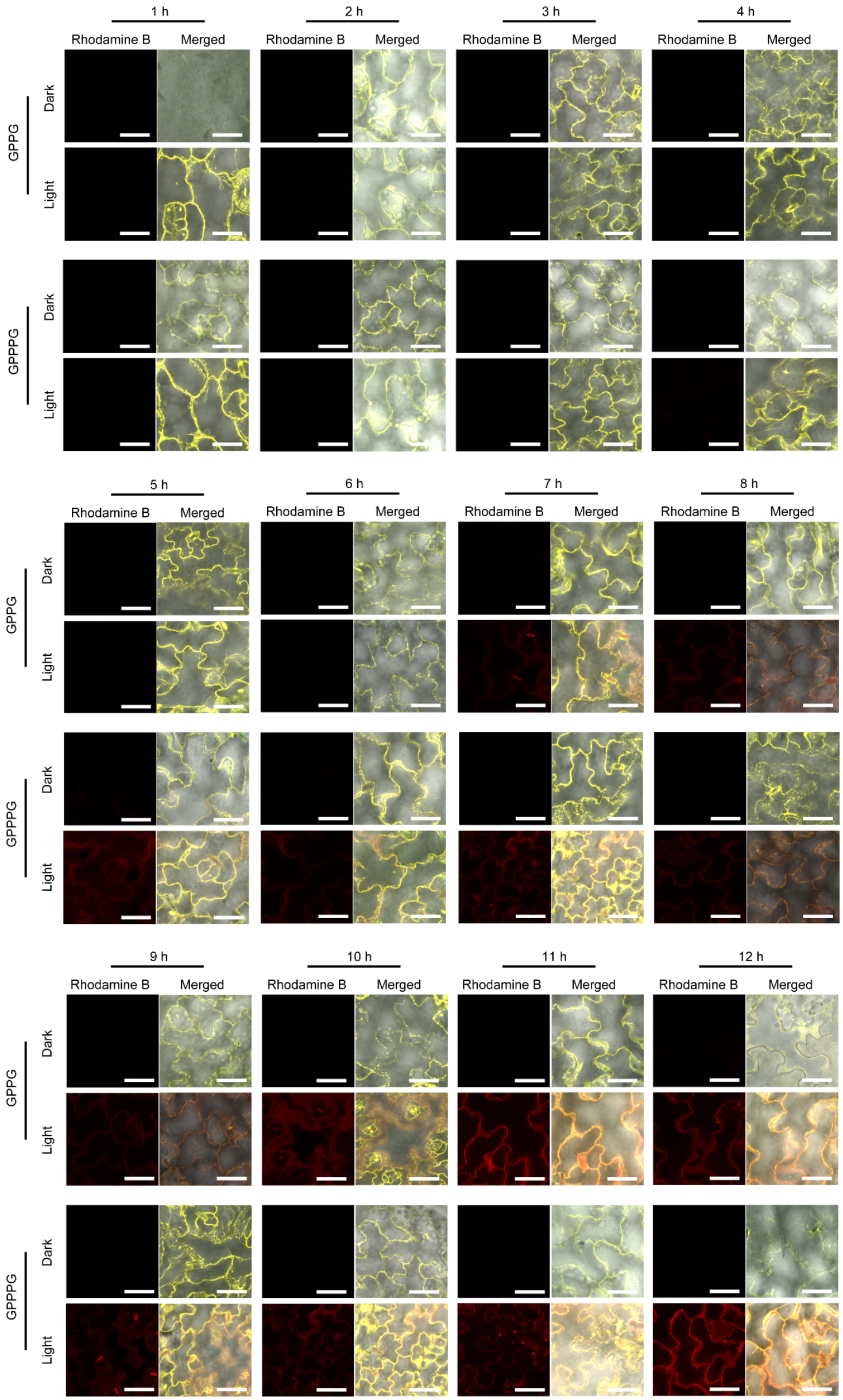
Figure S9. Time course for the release of rhodamine B from peptide nanoparticles in $A$. thaliana leaves. 

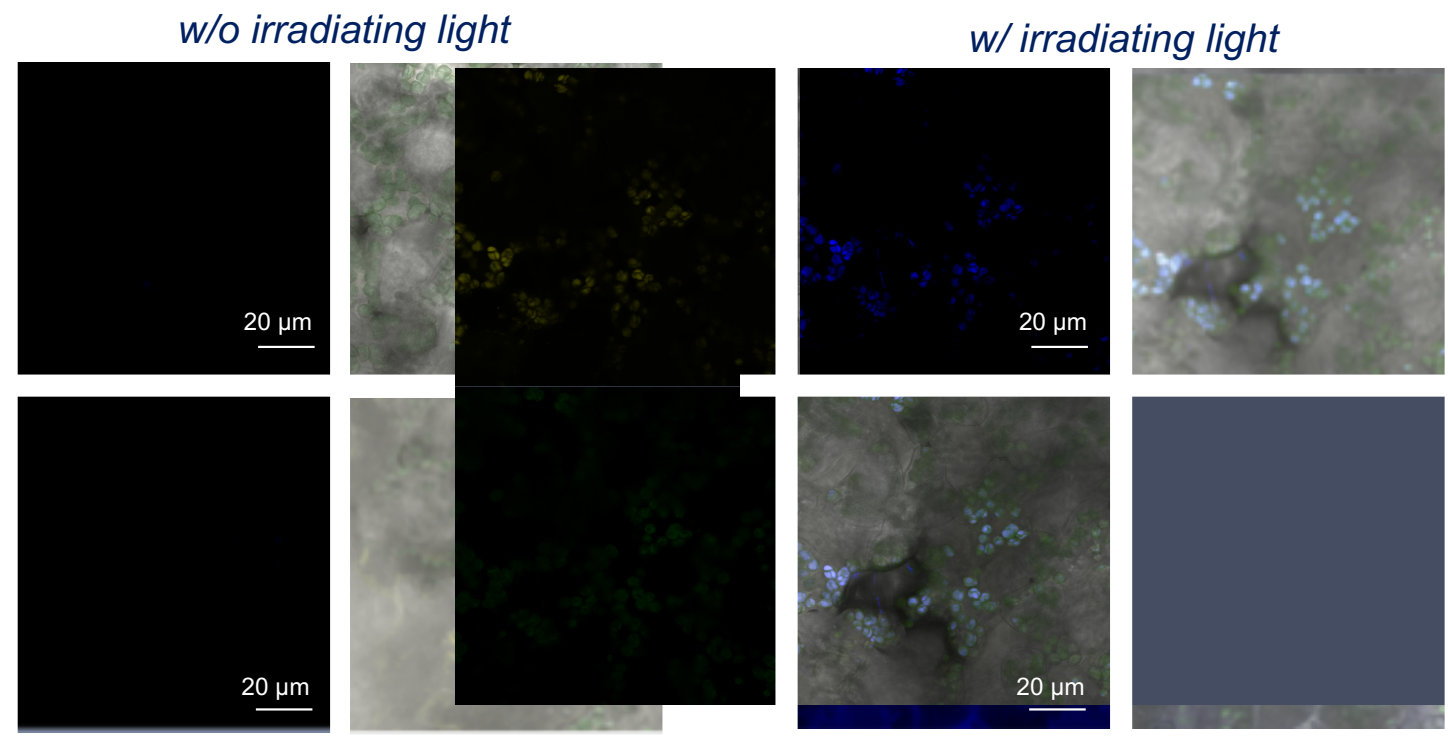

Figure S10. Subcellular distribution of ROS detected by a fluorescent probe $\mathrm{H}_{2}$ DCFDA in $A$. thaliana leaves after $12 \mathrm{~h}$ incubation (blue: $\mathrm{H}_{2}$ DCFDA, green: chlorophyll). 


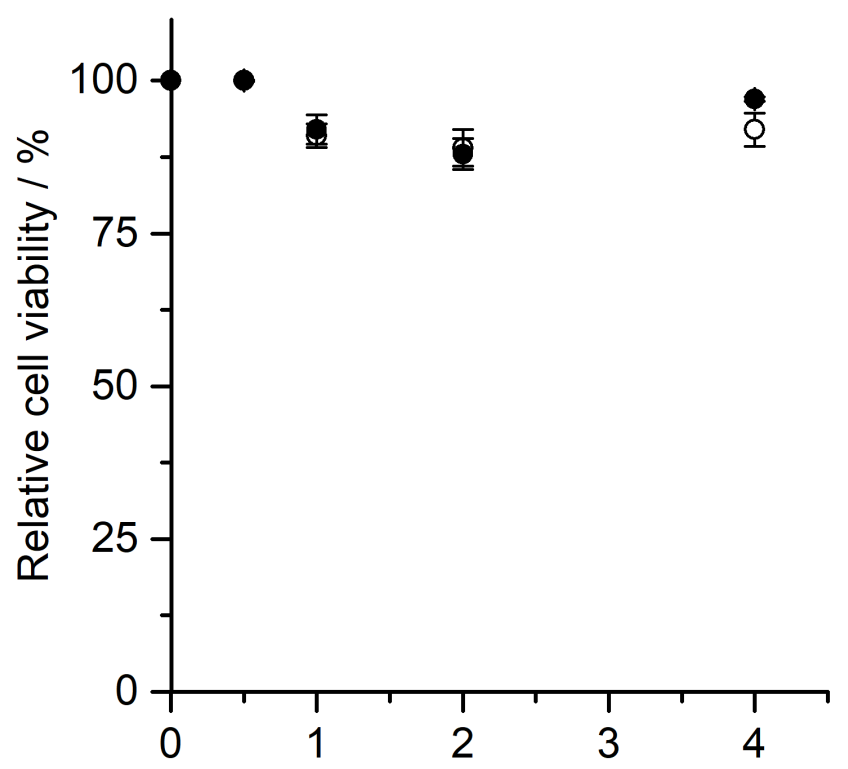

Peptide concentration / $\mathrm{mg} \mathrm{mL}^{-1}$

Figure S11. Cytotoxicity of oligoproline-containing peptide nanoparticles against plant leaf cells. The peptides were administrated into $A$. thaliana leaves via infiltration $\left(0-4 \mathrm{mg} \mathrm{mL}^{-1}\right.$, $100 \mu \mathrm{L})$. After $24 \mathrm{~h}$ incubation, the cytotoxicity was determined by evans blue assay $(\mathrm{n}=3)$. 
Movie S1. Site-selective release of rhodamine B from GPPPG peptide nanoparticles in $A$. thaliana leaf. CLSM images of the leaf were continuously obtained with a laser irradiation at $488 \mathrm{~nm}$ in the circles. Left top: chlorophyll (green), right top: rhodamine B (red), left bottom: YFP (yellow), right bottom: merged image. 